\title{
Rootstocks as possible alternative uses for pear trees cultivar select
}

\begin{abstract}
Studies to evaluate the effect of rootstock on fruit growing are of extreme importance. For the pear culture (Pyrus sp.) it can be considered even more important, since in addition to the search for plants of lesser vigor, with the use of interspecific rootstock (Cydonia oblonga), the affinity between the parts must also be tested, graft and rootstock. The aim of this research was to evaluate the growth and development of pear tree cultivar Seleta grafted on four different rootstocks. The experiment was carried in Capão do Leão, RS, Brazil. On August 2002, the pear trees were planted at $5 \mathrm{mx} 1 \mathrm{~m}\left(2000\right.$ trees.ha $\left.^{-1}\right)$ and conducted in slender spindles system trained on three-wire support, using a dripping irrigation system was set for four hours a day $\left(2 \mathrm{Lh}^{-1} \mathrm{per}\right.$ tree). The rootstocks tested were three quinces (Cydonia oblonga) cultivars Adams, EMC and Portugal, and one Pyrus calleryana. The parameters evaluated were aspects vegetative and reproductive of plants. Quince had similar results, showing less vigor to 'Seleta', reducing plant height by $60 \%$ more than Pyrus calleryana. Also they were significantly different as comparing to the Pyrus calleryana rootstocks regarding their rootstocks and cultivar trunk diameter, tree height, canopy volume and pruning wood weight. 'Seleta' showed the largest trunk diameter $(4.63 \mathrm{~mm})$ whether it grafted on Pyrus calleryana, which might be in its early stages of grafting incompatibility. The findings indicated that Pyrus calleryana rootstock promoted further tree vigor, which factor is not desirable for high density plantings. The rootstock Pyrus calleryana, showed higher yield $\left(0.9\right.$ tha $\left.^{-1}\right)$ compared to quince. However, 'Adams' had the better diameter relation between both cultivar and rootstock, being a good indicator of 'Seleta'/rootstock compatibility.
\end{abstract}

Keywords: Cydonia oblonga, Pyrus spp., grafting, pear, orchard
Volume 2 Issue 3 - 2018

\author{
Clevison Luiz Giacobbo,' Doralice Lobato \\ de Oliveira Fischer, ${ }^{2}$ Alison Uberti \\ 'Department of Agronomy, Federal University of Fronteira Sul, \\ Brazil \\ ${ }^{2}$ Department of Fruticulture, Viticulture and Enology Academic \\ Center, Brazil
}

Correspondence: Clevison Luiz Giacobbo, Department of Agronomy and PPGCTA, Campus Chapecó, Federal University of Fronteira Sul, Rodovia SC 484, Km 02, Fronteira Sul, Chapecó, SC, Brazil,Tel 898I5899, Email clevison.giacobbo@uffs.edu.br

Received: January 12, 2018 | Published: May 25, 2018

\section{Introduction}

Among temperate fruits, grown worldwide in the period 2000 to 2008 the culture of pear showed the second highest growth with $29.2 \%$ of production, behind only peach and nectarine $34.8 \%$, followed by plum with $21.3 \%$, and apple with $17.9 \%$. However, in the last decade, it presented a more moderate behavior when compared to the growth of other fruits, being in the tenth position among temperate fruits, but nevertheless presented a much higher growth $(121.2 \%)$ between the years of 2010 and 2016, a difference of $92 \%$ more than the previous period. ${ }^{1}$ Despite the increase in world production in Brazil, the pear has negligible production $(9.6 \%)$ with only 14,905 ton.ano ${ }^{-1},{ }^{2}$ while its consumption reaches more than 150,000 ton.ano ${ }^{-1}$, being imported in 2018, according MDIC $^{3} 156,185.7$ tons, to meet the internal need, which had the highest expenditure for import with this culture. In this context, Brazil is the fourth largest importer of pears and the product is first on the list of imported fruit, massively acquired from Argentina (55\% of total), which is the largest exporter of this fruit. ${ }^{1-3}$ The correlation between pear and consumption in Brazil shows the great potential of expansion of the particular fruit. Mainly in southern Brazil, due to adequate climate conditions to the crop.

In this context, research work related to adaptation and behavior of pear cultivars and rootstocks has been accomplished, Giacobbo et al. ${ }^{4}$ in a study with the cultivar Carrick found that rootstocks with larger diameter of the trunk, provide the plants, the greater weight of pruning and productive efficiency and cv. Carrick reduced in height in $44.62 \%$ when grafted on quince 'DuLot' in relation to the quince 'EMC', considered dwarf. Rootstock vigor might be of paramount importance on pear production. High vigor may induce a delay in yield maturity, and when it associates to a high yield the scion will produce late-ripening. Therefore, a late-maturing cultivar is suitable for this case, once an early-maturing variety will be affected on its precocity and fruit ripening. According Francescatto et al., 5 rootstocks with less vigorous, can presented higher level of graft-incompatibility between scion and rootstock, as the case of quince rootstocks of pear, cultivars 'EMC' and 'Portugal', were the rootstocks that showed the more marked degree of incompatibility in the cvs work with pear trees 'Carrick', 'Packham's Triumph ', 'seleta' and 'William's'. During nursery period, the canopy growth on different rootstocks is, in general, visually similar both in vigorous or no-vigorous rootstocks. So, the vigor difference can be more visible when the trees are transferred to the field. The present study had the main purpose to assess the influence of different quinces rootstocks and Pyrus calleryana on growth and development of pear trees cultivar 'Seleta'.

\section{Materials and methods}

The research was carried out at the experimental field of Palma Agricultural Center and at the laboratory of Federal University of Pelotas (FAEM/UFPEL), Capão do Leão, RS, Brazil. It is located at $31^{\circ} 48^{\prime} 15^{\prime \prime} \mathrm{S}, 52^{\circ} 30^{\prime} 49^{\prime \prime} \mathrm{O}$ Greenwich and altitude of $42 \mathrm{~m}$, in the orchard with four years of deployment $(2005 / 06)$. The soil belongs to the 'Camaquã' mapping unity and it is classed as Red-Yellow Podozolic. ${ }^{6}$ According to the classification of Köppen, the climate of the region is classified as $\mathrm{C}$, subtype Cfa (Subtropical climate), with cold and humid winter and mild and dry summer. The monthly average temperatures (minimum and maximum) and rainfall of the studied 
period are shown in Table 1. Orchard fertilization was performed according to recommendations to pear crop (NPK, base + B in leaves) and a drip irrigation system was standardized for all plants, four hours per day $(2 \mathrm{~L} / \mathrm{h}$ per tree). The experiment was conducted with pear tree cultivar 'Seleta' grafted on three different quinces (Cydonia oblonga) rootstocks cultivars 'Adams', 'EMC' and 'Portugal' and on Pyrus

Table I Weather conditions of the experimental field located at the municipality of Capão do Leão, in the State of Rio Grande do Sul, Brazil ${ }^{6}$

\begin{tabular}{|c|c|c|c|c|c|c|}
\hline \multirow{3}{*}{ Month } & \multicolumn{4}{|c|}{ Monthly average temperature $\left({ }^{\circ} \mathrm{C}\right)$} & \multirow{2}{*}{\multicolumn{2}{|c|}{$\begin{array}{l}\text { Monthly rainfall } \\
(\mathrm{mm})\end{array}$}} \\
\hline & \multicolumn{2}{|c|}{ Minimum } & \multicolumn{2}{|c|}{ Maximum } & & \\
\hline & 2005 & 2006 & 2005 & 2006 & 2005 & 2006 \\
\hline January & 19 & 19.3 & 30.4 & 29.6 & 70.4 & 122.8 \\
\hline February & 19.1 & 17.8 & 27.9 & 28.6 & 96.4 & 82.8 \\
\hline March & 17.4 & 17.8 & 28.2 & 27.5 & 71 & 135.6 \\
\hline April & 13.7 & & 23.8 & & 166.6 & \\
\hline May & 12.4 & & 21.3 & & 99 & \\
\hline June & 13.4 & & 21.6 & & 28.2 & \\
\hline July & 8.9 & & 19.4 & & 42.2 & \\
\hline August & II.I & & 20.7 & & 94.8 & \\
\hline September & II.3 & & 18.2 & & 241.6 & \\
\hline October & 13.2 & & 21.5 & & 93.3 & \\
\hline November & 15.5 & & 27.3 & & 23.7 & \\
\hline December & 16.1 & & 27 & & 45.6 & \\
\hline
\end{tabular}

'Data obtained from the weather station located at the municipality of Pelotas, ${ }^{14}$ in the state of Rio Grande do Sul, Brazil. ${ }^{6}$

1. Development of trunk diameter - a digital paquimeter was used at $10 \mathrm{~cm}$ above and below the grafting point and the difference between scion and rootstocks was taken.

2. Tree height - measured from the ground to the top of the tree $(\mathrm{cm})$.

3. Canopy volume - by multiplication of height, width and canopy thickness $\left(\mathrm{m}^{3}\right)$.

4. Average area of leaves - the sample consisted of 10 leaves per tree and the leaf area was determined by using a leaf area measurer $\left(\mathrm{cm}^{2}\right)$.

Table 2 Rootstock and scion trunk diameter, diameters difference, tree height, canopy volume and pruning weight of pear tree cultivar 'Seleta' grafted on different rootstocks ${ }^{14}$

\begin{tabular}{lllllll}
\hline Cultivars & \multicolumn{2}{l}{ Diameter $(\mathbf{m m})$} & $\begin{array}{l}\text { TDD } \\
(\mathbf{m m})\end{array}$ & Tree height $\mathbf{( c m )}$ & $\begin{array}{l}\text { Canopy volume } \\
\left(\mathbf{m}^{3}\right)\end{array}$ & Pruning weight $(\mathbf{g})$ \\
\hline P. calleryana & $33.700 \mathrm{a}^{1}$ & $38.330 \mathrm{a}$ & $-4.630 \mathrm{c}$ & $217.230 \mathrm{a}$ & $0.673 \mathrm{a}$ & $111.520 \mathrm{a}$ \\
Adams & $15.110 \mathrm{~b}$ & $13.990 \mathrm{~b}$ & $1.110 \mathrm{a}$ & $99.100 \mathrm{~b}$ & $0.05 \mathrm{lb}$ & $6.060 \mathrm{~b}$ \\
EMC & $11.470 \mathrm{~b}$ & $13.020 \mathrm{~b}$ & $-1.550 \mathrm{~b}$ & $75.050 \mathrm{~b}$ & $0.001 \mathrm{~b}$ & $1.080 \mathrm{~b}$ \\
Portugal & $11.090 \mathrm{~b}$ & $12.920 \mathrm{~b}$ & $-1.840 \mathrm{~b}$ & $90.920 \mathrm{~b}$ & $0.002 \mathrm{~b}$ & $0.000 \mathrm{~b}$ \\
C.V. (\%) & 34.9 & 35 & -126.8 & 32.8 & 214.3 & 296.8
\end{tabular}

'Means with the same letter are not significantly different by Duncan test $(\alpha=0.05)$.

${ }^{2}$ TDD - Difference between trunk and scion diameter.

calleryana. On August 2002, the pear trees were planted at $5 \times 1 \mathrm{~m}$ $(2000$ trees/ha) and conducted in slender spindles system trained on three-wire support. The experimental design utilized was a complete randomized block with three replications of four trees each. Data collected were:

5. Fresh and dry leaf weight - after assessment of leaf area, the leaves were weighed to determine the fresh matter. Then, they were taken into the oven to dry out during $15 \mathrm{~min}$ to determine dry matter $(\mathrm{g})$.

6. Productivity - estimated per hectare.

7. Yield efficiency $-\mathrm{Kg}$ fruit. $\mathrm{cm}^{-2}$ trunk diameter (Adapted from Tomei, ${ }^{7}$ Giacobbo $^{8}$ ).

The data were submitted to analyses of variance F-test and the comparison of means between treatments was applied when the comparative data were statistically significant. The means differences were separated with Duncan test at 5\% level of significance. The statistical analyses were performed by using WinStat program. ${ }^{9}$

\section{Results and discussion}

Pyrus calleryana trunk diameters were the largest and significantly different compared to cultivars 'Portugal', 'EMC' and 'Adams'. The same occurred to scion trunk diameter. In regards to trunk diameter difference, the scion growth was always superior to the rootstocks 'Portugal', 'EMC' and Pyrus calleryana. However, the rootstock 'Adams' was larger in diameter than the scion, being statistically different from other rootstocks (Table 2). Regarding tree height, the cultivars 'EMC', 'Portugal' and 'Adams' showed a decrease in trunk diameter and lesser vigor, differing from Pyrus calleryana, which enhanced pear tree height of 'Seleta'. The same occurred with the variables canopy volume and weight of pruning branches (Table 2 ). The trees of cultivar 'Seleta' had their vigor altered to $65.45 \%$, $58.15 \%$ and $54.38 \%$ when propagated on quinces rootstocks 'EMC', 'Portugal' and 'Adams', respectively, in relation to more vigorous Pyrus calleryana. The results found in this experiment in regards to the similarity of rootstocks behavior at all variables assessed agree with studies on pear rootstocks for Italy conditions carried out by Giacobbo $^{8} \&$ North et al. ${ }^{10}$ They found that the rootstocks showing large area of trunk transversal section provided vigorous tree, but not necessarily high yield. 
The vigor difference among the rootstocks tested can be explained by Baldini ${ }^{11}$ as being related to the anatomic structure of root and trunk. In particular, the less vigorous rootstocks show a welldeveloped root epidermis in relation to woody cylinder of the more vigorous rootstocks. Furthermore, the more vigorous rootstocks show wide vases with higher porosity, consequently higher specific hydric conductibility. For the leaf area results, the rootstocks Pyrus calleryana provided larger leaves $\left(111.72 \mathrm{~cm}^{2}\right)$ whether compared to 'Portugal' (79.37 $\mathrm{cm}^{2}$ ) (Table 3). This is backed up with Faust, ${ }^{12}$ who associates the difference of leaf area development with plant development, as height, canopy volume and trunk diameter. Similar results were checked by Giacobbo et al., ${ }^{4}$ which found that the rootstock that led to less vigorous plant also presented lower leaf areas. There were no significant differences of fresh and dry leaves weight of 'Seleta' raised on the different rootstocks (Table 3). Distinct results were observed by Giacobbo, ${ }^{8}$ with the cultivars 'William's Bon Chrétien' and 'Packham's Triumph' grafted on different rootstocks. They considered the fresh and dry weight as a parameter of plant development. Due to variability of water content in the plant, the dry weight rate corresponds to the plant growth. Thus, the dry weight is considered more accurate than fresh weight for the estimation of plant growth. However, in work with different citrus rootstocks Fadli et al., ${ }^{13}$ did not find significant directions for both the fresh weight and the dry weight of the leaves. Regarding productivity, the fourth year of cultivation, it was found that when grafted pear cv. Select on the rootstock Pyrus calleryana, showed higher yield (0.9t.ha $\left.{ }^{-1}\right)$ compared to quince. But when measured yield efficiency, there was no significant difference between treatments, averaging $14.4 \mathrm{~kg}$ fruits. $\mathrm{cm}^{-2}$ trunk diameter.

Table 3 Leaf area, fresh and dry matter, production, yield efficiency of pear tree cultivar 'Seleta' grafted on different rootstocks ${ }^{14}$

\begin{tabular}{|c|c|c|c|c|c|}
\hline Cultivars & Leaf area $\left(\mathrm{cm}^{2}\right)$ & Fresh leaf weight (g) & Dry leaf weight (g) & productivity (t.ha- $\left.{ }^{-1}\right)$ & $\begin{array}{l}\text { Yield efficiency }\left(\mathrm{Kg} \cdot \mathrm{cm}^{-2}\right. \\
\text { trunk diameter })\end{array}$ \\
\hline P. calleryana & III.720a' & $2.800 \mathrm{a}$ & $1.310 \mathrm{a}$ & $0,940 \mathrm{a}$ & $23,750^{\text {ns }}$ \\
\hline Adams & $99.080 \mathrm{ab}$ & $2.360 \mathrm{a}$ & I.I70a & $0,210 \mathrm{~b}$ & I I,880 \\
\hline EMC & $102.950 \mathrm{ab}$ & $2.920 \mathrm{a}$ & $1.730 \mathrm{a}$ & $0,090 b$ & 10,630 \\
\hline Portugal & $79.370 \mathrm{~b}$ & $2.300 \mathrm{a}$ & $1.390 \mathrm{a}$ & $0,130 b$ & $\mathrm{II}, 250$ \\
\hline C.V. (\%) & 17.3 & 26 & 33.9 & 235.2 & 226.5 \\
\hline
\end{tabular}

'Means with the same letter are not significantly different by Duncan test $(\alpha=0.05)$.

${ }^{\mathrm{ns}}$ non significant.

\section{Conclusion}

1. Rootstocks showing large diameter provided tree with large canopy volume and higher height;

2. The cultivar 'Seleta' had less vigor when grafted on quinces rootstocks 'EMC', 'Portugal' and 'Adams' (65.45\%, 58.15\% e $54.38 \%$, respectively), in relation to more vigorous Pyrus Calleryana;

3. Pyrus calleryana rootstocks, more vigorous, has initially increased productivity compared to quince.

\section{Acknowledgements}

None.

\section{Conflict of interest}

Authors declare that there is no conflict of interest.

\section{References}

1. FAO. FAOSTAT data. 2018

2. IBGE (Instituto Brasileiro de Geografia e Estatística)/SIDRA (Sistema IBGE de Recuperação Automática). Produção Agrícola Municipal; 2018

3. MDIC (Ministério do Desenvolvimento, Indústria e Comércio Exterior). Comex Vis: Main Imported Products - Fresh Pears; 2018.

4. Giacobbo CL, Gazolla NA, Pazzin D, et al. The assessment of different rootstocks to the pear tree cultivar carrick. Acta Horticulturae. 2010;872:353-358.
5. Francescatto P, Pazzin D, Gazolla Neto A, et al. Evaluation of graft compatibility between quince rootstocks and pear scions. Acta Horticulturae. 2010;872:253-260.

6. Brasil. Ministério da Agricultura. National Department of Agricultural Research / Pedological Research Division. Soil Reconnaissance Survey of the State of Rio Grande do Sul Recife; 1973:431.

7. Tomei F. Comportamento vegeto-produtivo dei principali portinesti Del pero e Del melo in província di Pisa. Tesi di laurea (Agronomia) Università degli studio di Pisa. 2001;149.

8. Giacobbo CL. Rootstocks for the culture of the European pear tree type. Federal University of Pelotas. 2006.74.

9. Machado A, Conceição AR. Statistical program winstat - Statistical Analysis System for Windows version 2.0. Pelotas. 2005.

10. North M, Kock KDE, Booyse M. Effect of rootstock on 'Forelle' pear (Pyrus communis L.) growth and production. South African J Plant and Soil. 2015;32(2):65-70.

11. Baldini E. Arboricoltura generale. Clueb. Bologna;1986:396.

12. Faust M. Physiology of temperate zone Fruit Trees. John Wiley \& Sons: New York;1989:338.

13. Fadli A, Chetto O, Talha A, et al. Characterization in greenhouse conditions of two salt tolerant citrumelo (Citrus paradisi Macf. x Poncirus trifoliata (L.) Raf.) Cultivars. Journal of Life Sciences. 2014;8:955-966.

14. Estação agroclimatológica de pelotas (Capão do Leão). Boletim Agroclimatológico. 2015. 